\title{
Female Genitalia
}

National Cancer Institute

\section{Source}

National Cancer Institute. Female Genitalia. NCI Thesaurus. Code C61600.

The external female sexual organs. 